\title{
The impact of organization culture on competitive advantage "An empirical study of hotels and tour operators in Egypt"
}

\author{
Ibrahim A.Elshaer \\ Alaa Shaker Azazz \\ Faculty of Tourism and Hotels - Suez Canal University
}

\begin{abstract}
The aim of this paper is to analyze the impact of organizational culture (OC) on the company competitive advantage (CA). The organizational culture has received significant attention recently. The literature on the organizational culture constantly supports the idea that this culture is significant for effectiveness and performance of the organizations. Although numerous studies have been conducted to explore the relationship between the organizational culture and performance, empirical findings seem to be mixed and inconclusive. Moreover, a limited number of studies examine the relationship between OC and CA, particularly in the tourism industry, a gap this study aims to fill. Data was collected from surveying employees working in five-star hotels and in tour operators companies. The variables' reliability was analyzed by the composite reliability (CR); dimensional structure of the study variables was tested using exploratory factor analysis (EFA), CFA was employed to test the variables validity, and finally, multi-group analysis in structural equation modeling (SEM) was employed to test the causal link among the research variables. The study results and implications are discussed and justified.
\end{abstract}

\section{Introduction}

Organizations struggle to survive nowadays competitive world (Fekete and Borsckei, 2011). They are trying to find methods to be more competitive, innovative, and creative (Madu, 2014). Building on Barney (1996) resource-based view (RBV) theory, organization culture (OC) can be considered as one of the intangible resources the firm can utilize to increase performance and gain a competitive advantage (CA). Numerous theoretical and empirical studies have been conducted to explore the relationship between the organization culture and its outcomes including financial performance (FP) and CA, however, findings seem to be contradictory (Yesil and Kaya, 2013). More specifically, some authors (i.e. Kim et al., 2004; Oparanma, 2010; Zheng et al., 2010; Duke II \& Edet, 2015) argue that OC positively affects FP. Another group of papers finds no association between OC and performance (Yesil and Kaya, 2013). However no empirical studies (to the authors' knowledge) were found to test the relationship between OC and CA in the tourism industry (table 1), a gap this study aims to fill. Therefore, it seems that more research is needed for understanding and exploring the relationship between OC and CA (Yesil and Kaya, 2013), particularly in the tourism industry. See table 1.

Table 1: Database search
\begin{tabular}{|l|l|l|l|l|l|}
\hline Keywords/ Database & $\begin{array}{l}\text { Organization } \\
\text { culture }\end{array}$ & $\begin{array}{l}\text { Organization } \\
\text { culture \& } \\
\text { financial } \\
\text { performance }\end{array}$ & $\begin{array}{l}\text { Organization } \\
\text { culture \& } \\
\text { competitive } \\
\text { advantage }\end{array}$ & $\begin{array}{l}\text { OC \& in } \\
\text { tourism } \\
\text { industry }\end{array}$ & $\begin{array}{l}\text { OC \& CA in } \\
\text { industry in } \\
\text { Egypt }\end{array}$ \\
\hline SAGE journal & & & & 0 & \\
\hline Science direct & 40794 & 4120 & 5 & 0 & 0 \\
\hline Emerald (All resources) & 186 & 0 & 0 & 0 & 0 \\
\hline Wiley (books) & 290 & 39 & 2 & 2 & 0 \\
\hline Google scholar sjosm & 1310 & 63 & 0 & 0 & 0 \\
\hline Total & 46571 & 5486 & 7 & 0 & 0 \\
\hline
\end{tabular}




\section{Literature review}

\section{Culture and organization culture}

The concept of organizational culture has received a great deal of attention both from academics and managers and defined from many perspectives in the literature (Madu, 2012). However, there is little agreement on the meaning, outcomes of organization culture and how it could be operationalized or measured, and how it could be employed to improve the organization performance (Schein, 1990).

Organizational culture emerges from two distinct fields (Anthropology and sociology) and became a popular topic of organizational research in marketing and management (e.g. Gregory et al., 2009; Maleka, \& Kambuwa, 2010; and Naik, 2011). Anthropology accepted the interpretivist view and considers culture as a symbol for associations, defining associations as being cultures. Then again, sociology goes up against the functionalist view and explains culture as something an association has (Sanchez-Canizares et al., 2007 and Prem, 2011).

Despite the growing interest in the topic (OC), there seems to be no agreement or consensus within the literature as to what organizational culture actually constitutes (O'Reilly, Chatman \& Caldwell 1991, Barney, 1986; Abu-Jarad et al., 2010). Madu (2012) concluded that a practical way to define organizational culture is the environment in which we work; i.e. these are the member's behaviors, attitudes, beliefs, skills, perspectives, habits, and prejudices. Some of these attributes have been formed by previous leaders, either bad or good through years of influence and reinforcement. So, leaders of organizations are responsible for the climate they create in their organization.

In the current study we a adopted a wide common definition of the organizational culture developed by O'Reilly \& Chatman, $(1996,2014)$ "a system of shared values defining what is important, and norms, defining appropriate attitudes and behaviors" Norm's help individuals follow the behaviors which are important to their organizational setting (O'Reilly\& et al., 2014).

According to the previously mentioned, there is a general agreement that organizational culture refers to individuals' shared norms, values, meanings, beliefs and principles which are held within the organization and forms part of the socialization process of new employees (Naik, 2011). In other words, organizational culture refers to the values and beliefs that provide norms of expected behaviors that employees might follow (Schein, 1992, Hogan \& Coote, 2013).

\section{Strong versus weak organization culture}

Kotter and Heskett (1992) assumed that strong culture firms would perform better over the long term. They claimed that the presence of strong culture, which they explain in terms of values and norm shared among individuals of the association, ought to be related to higher objective alignment among association employees, encourage an uncommon level of motivation among employees, and provide needed controls without the effect of bureaucracy (O'Reilly and Chatman, 1996).

Organizational culture is important in organizations because it refers to created assumptions, which are accepted as a way of doing things and are passed on to new members of the organization. For new employees, this would mean adaptive behavior within the organization that leads to new belief systems. This new and adaptive behavior is instilled through organizational values and beliefs that are associated with rituals, myths and symbols to reinforce the core assumptions of organizational culture (Hofstede, 1991; Martins and Martins, 2003).

The benefits of the culture in organizations direct the organization towards goal attainment, organizational success, enhance organizational citizenship, loyalty, customer satisfaction, motivation and increase the consistency of employees' behaviour (Pressing and Loennies, 2011; Martins and Von der Ohe, 2006; Martins and Martins, 2003; Robbins, 2005; Struwig and Smith, 2002). Also, culture is able to create a unifying force that increases organizational performance and it is able to positively affect employee behavior, the financial performance of the organization and creates a competitive advantage (Ledimo, 2015; Manetje and Martins, 2009; Ivancevich et al, 2005; Werner, 2007; Mazur, 2010; Madu, 2012; Davidson, 2003 and Barney, 1991).

When a great number of employees embraces the same kind of beliefs and values as a concern to the organization, Culture of the association is viewed as strong (Deal and Kenedy, 1982). Managers should try to 
narrow the gap between employees to develop a strong relationship. Management also believes that employees are more important than rules in the organization. Strong culture plays an important role to improve the performance of the employees. It increases self-confidence and commitment of employees' and lessens job stress and improves the ethical behavior of the employees (Saffold, 1998). Additionally, Deal and Kennedy (1982) claimed that both weak and strong culture has a great effect on the organizational behavior but in the strong culture, employee's aims are sided with the goal of management and helpful in increasing the overall organizational performance. A stronger organizational culture has positive great effects on people and group behavior (Trefry, 2006 and Testa \& Sipe, 2011).

\section{Table: 2 Strong versus Weak OC}

\begin{tabular}{|c|c|}
\hline Strong Cultures & Weak Cultures \\
\hline Values widely shared & $\begin{array}{l}\text { Values limited to a few people-usually } \\
\text { top management }\end{array}$ \\
\hline $\begin{array}{l}\text { Culture conveys consistent messages about } \\
\text { what's important }\end{array}$ & $\begin{array}{l}\text { Culture sends contradictory messages } \\
\text { about what's important }\end{array}$ \\
\hline $\begin{array}{l}\text { Most employees can tell stories about } \\
\text { company history/heroes }\end{array}$ & $\begin{array}{l}\text { Employees have little knowledge of } \\
\text { company history or heroes }\end{array}$ \\
\hline Employees strongly identify with culture & $\begin{array}{l}\text { Employees have little identification with } \\
\text { culture }\end{array}$ \\
\hline $\begin{array}{l}\text { Strong connection between shared values } \\
\text { and behaviors }\end{array}$ & $\begin{array}{l}\text { Little connection between shared values } \\
\text { and behaviors }\end{array}$ \\
\hline
\end{tabular}

Source: Robbins et al., (2011)

\section{Competitive advantage and Organization Culture}

Mooney (2007) defined the competitive advantage as "achieving above average performance in the same industry". The understanding of the way to gain a competitive advantage for firms has become a main area of interest for several researchers in the area of strategic management (Porter, 1985). Past studies have looked extensively at the relationship between $\mathrm{OC}$ and its potential outcomes including: performance and commitment (Kotter \& Heskett, 1992; LeBlanc \& Mills, 1995; Lok \& Crawford, 2003; Xenikou \& Simosi, 2006; and Naik,2011), organizations effectiveness and efficiency (Dennison,1990; Dennison \& Mishra, 1995; Earley \& Mosakowski, 2000, Denison \& Mishra, 1995; and Kemp \& Dwyer, 2001), work-related attitudes (Bimbaum \& Sommers, 1986) and profitability (Tidball, 1988).

As several empirical and Theoretical studies have been conducted to examine the relationship between organizational culture and performance, empirical findings seem to be mixed and sometimes contradictory (Yesil and Kaya, 2013). Theoretical arguments support the idea that the organizational culture is related to organizational performance and long-term effectiveness (Ahmed, 1998; Cameron \& Quinn, 2006; Saffold, 1988; Zheng et al., 2010). In the same vein, Zheng et al., (2010) claimed that the organizational culture is one of the main organization's intangible assets that have been researched widely in their association with organizational performance. Oparanma (2010) argued that organizational culture prompts or stimulates many other activities that bring about corporate success.

Empirical studies also provide an evidence of a link between organizational culture and organization related performance outcomes. Marcoulides \& Heck (1993) asserted that organizational culture has a strong direct effect on the organizational performance. Kim et al., (2004) stated that culture was found to affect different organizational processes and performance. The strong cultural values were found to be correlated with the organizational performance of firms in a few cases. Oparanma (2010) and Duke \& Edet (2012) found that organizational culture is an important variable to be considered when organizational performance is in consideration. According to results, there is a positive relationship between organizational culture and performance. However, this positive effect is negligible when a mediator is involved (Zheng et al., 2010). On the other hand, some authors claimed that the direct impact of OC on firm performance is not supported but can be supported indirectly through some other mediating variables such as knowledge conversion (Tseng, 
2010), knowledge management (Zheng et al., 2010), and innovativeness (Han et al., 1998). Even the findings provide indirect support for these theoretical and empirical studies, it is really difficult to reach a conclusion that organizational culture dimensions do not affect performance outcomes. Yesil, and Kaya (2013) suggest that it is advisable to further explore direct and indirect culture-performance relationship in different contexts with different measurements and research designs. For instance, Kim et al., (2004) concluded that culture can affect organization performance if it is strong (wide consensus, deeply internalized and socialized) and appropriate to its environment (relevant to its industry and business conditions)

Trefry (2006) indicated that organizational culture is even more critical in multicultural organizations (i.e. hotels and travel agencies), because of its positive impact on the benefits and challenges of employee cultural diversity -and thus on organizational performance, organizational learning and potential competitive advantage. Therefore, more research might be needed to improve our understanding of the nature of the relationship between organizational culture and competitive advantage in a multicultural organization. The relatively fewer studies coming from developing countries stimulated the authors to take a step forward and test the impact of organization culture on the competitive advantage (superior financial performance) in the Egyptian hotels and travel agencies organizations.

\section{Research framework and hypotheses}

A critical review of the previous theoretical and empirical studies that investigated the link between OC and its outcomes including financial performance and competitive advantage has been conducted as previously discussed. This literature review has assisted in proposing a conceptual framework to serve the purpose of the current study and consists of the following six hypotheses illustrating the direct link between organization culture dimension and competitive advantage:

H1: Adaptability has a positive effect on the competitive advantage

$\mathrm{H} 2$ : Collaborative has a positive effect on the competitive advantage

H3: Result oriented has a positive effect on the competitive advantage

$\mathrm{H} 4$ Customer oriented has a positive effect on the competitive advantage

H5: Detail oriented has a positive effect on the competitive advantage

H6: Integrity has a positive effect on the competitive advantage

\section{Figure 1: Research framework and hypotheses}

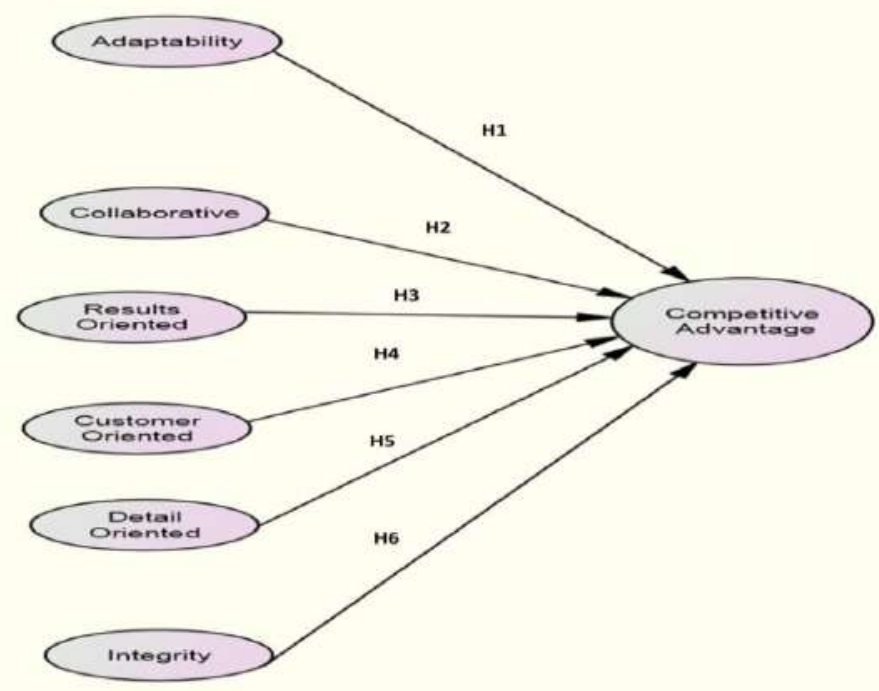




\section{Research Methods}

\section{Measures}

Numerous researchers have employed different scales to operationalize OC, such as the Competing Values Framework OCAI (Cameron and Quinn,1999), Organizational Social Context (OSC) ( Glisson, 2007), and the OC Profile (OCP) ( O'Reilly et al. , 1991-2014),

OCP by O'Reilly et al. (1991-2014), since its introduction has been revised and confirmed by several studies (e.g., Sarros et al., 2005; Sarros et al., 2008; Marchand et al., 2013; and Valmohammadi et a., 2015). OCP scale is an inclusive approach to describe OC on different dimensions. The original version of the OCP consists of seven dimensions: (1) attention to detail, (2), innovation and risk-taking (3) people orientation,(4), outcome orientation (5) aggressiveness, (6), team orientation (7) and stability. After more than 22 years, and according to changes in the environment (i.e. IT, globalization, and financial catastrophes) O'Reilly et al., (2014) refined the original seven dimensions of OCP to be six dimensions to make the scales' variables set more relevant, timely, and comprehensive.

The six dimensions and related description are employed in the current study and shown in the below table

Table 2: OC dimensions and descriptions.

\begin{tabular}{|c|c|}
\hline OC dimensions & Description \\
\hline Adaptability & $\begin{array}{l}\text { Being innovative, Risk-taking, Being willing to experiment, Fast-moving, } \\
\text { Being quick to take advantage of opportunities, Not being constrained by many } \\
\text { rules, Predictability }\end{array}$ \\
\hline Collaborative & $\begin{array}{l}\text { Working in collaboration with others, Being team-oriented, Cooperative, Being } \\
\text { supportive, Avoiding conflict, Confronting conflict directly }\end{array}$ \\
\hline Result oriented & $\begin{array}{l}\text { Having high expectations for performance, Achievement-oriented, Security of } \\
\text { employment }\end{array}$ \\
\hline Customer oriented & Being customer-oriented, Listening to customers, Being market driven \\
\hline Detail oriented & Paying attention to detail, Emphasizing quality, Being precise \\
\hline Integrity & $\begin{array}{l}\text { Having integrity, Having high ethical standards, Being honest, Respecting } \\
\text { individuals, Being fair }\end{array}$ \\
\hline
\end{tabular}

Source: adopted from O'Reilly et al., (2014)

\section{Competitive advantage operationalization (superior financial performance)}

This study adopted Barney (1996) measure of CA as superior FP. While FP is frequently operationalized using perceptual measures ( $\mathrm{Zu}$ et al., 2008), FP in this study was measured by using two objective indicators (average employee productivity and average total revenue) in the past three years, as perceptual measures usually have biases and errors (Bollen and Paxton 1998).

\section{Sampling and data analysis techniques}

Random sampling data was obtained from surveying 1300 employees working in five-star hotels and tour operator class A in Cairo, Sharm El Sheikh, and Hurghada cities in Egypt. A total of 550 responses (290 from five-star hotels and 260 from tour operator companies class A) were obtained using two data collection techniques: e-mails, and DCS. A number of 130 incompleted questionnaires were removed leaving 420 usable questionnaires and yielding a response rate of $42 \%$. 


\section{Results and Discussion}

\section{Dimensionality test}

EFA using SPSS version 22 was employed to test the dimensionality of the study variables, EFA result yields 6 dimensions of OC. A six-factor structure is suggested using the criterion of an eigenvalue greater than 1 and the extracted factors account for $87.6 \%$ percent of the total variance. Nine variables were removed due to weak factor loading below .40 leaving 25 variables for six dimensions: adoptability (7); collaborative (4); result oriented (3); customer oriented (3); detail oriented (3) and integrity

\section{Test of validity and reliability}

First order CFA was employed to test convergent and discriminant validity of the study construct. The $\chi^{2}$ GOF statistics indicate that the first order confirmatory factor analysis fits the data well $\chi^{2}(260, \mathrm{~N}=420)=$ 595.570, $\mathrm{P}=.000$ (Normed $\chi 2=2.291, \mathrm{RMSEA}=0.056, \mathrm{SRMR}=0.033, \mathrm{GFI}=0.901, \mathrm{CFI}=0.969$, $\mathrm{NFI}=0.946, \mathrm{IFI}=0.969, \mathrm{TLI}=0.964, \mathrm{PCFI}=0.839$, and PNFI $=0.820)$, see figure 2 .

Figure 2: first order CFA

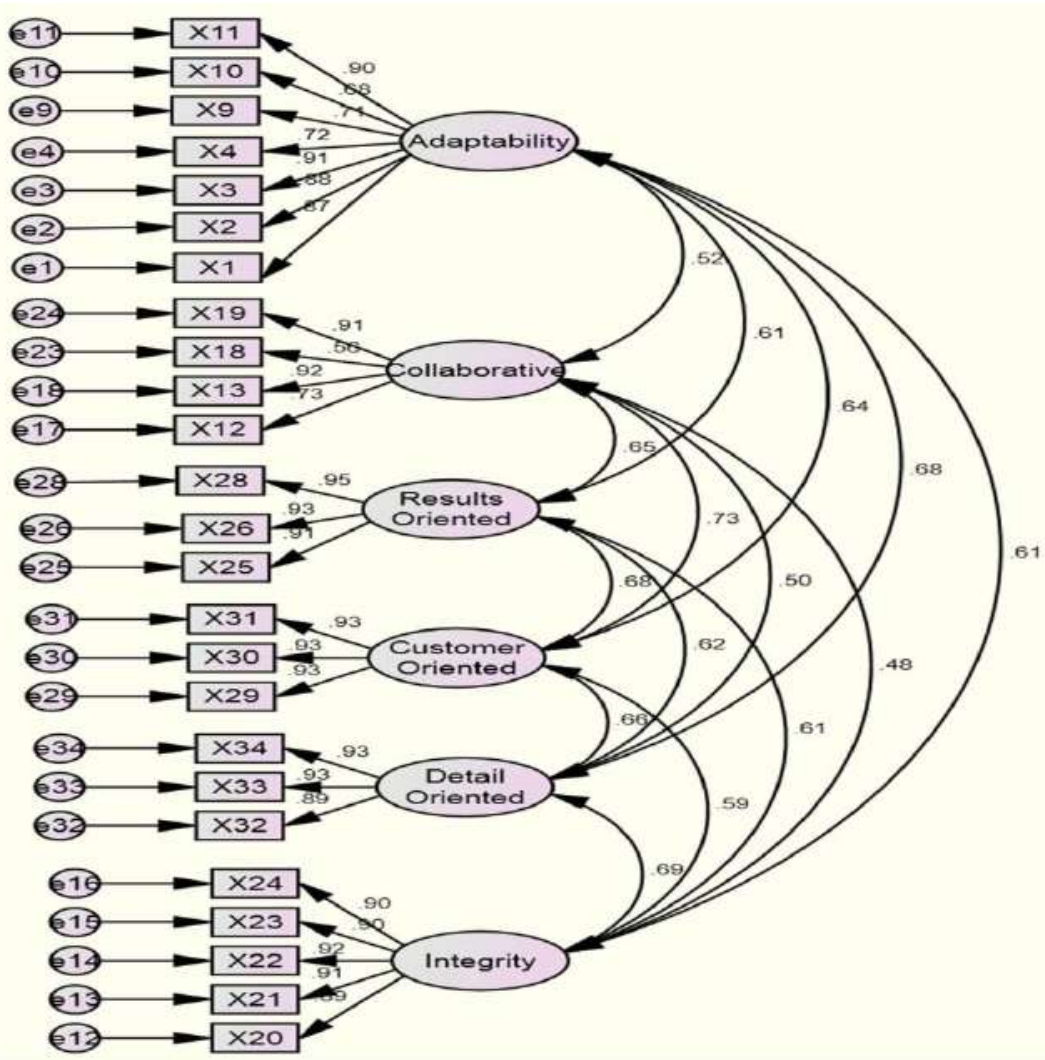

$$
\begin{gathered}
X^{2}(260, \mathrm{~N}=420)=595.570, \\
P=.000, \mathrm{CMIN} / \mathrm{df}=2.291, \\
\mathrm{RMSEA}=.056, \mathrm{GFI}=.901, \\
\mathrm{SRMR}=.033, \mathrm{CFI}=.969, \\
\mathrm{NFI}=.946, \mathrm{IFI}=969, \mathrm{TLI}=.964, \\
\mathrm{PCFI}=.839, \mathrm{PNFI}=.820
\end{gathered}
$$

Convergent validity of the current study was achieved by CFA through three main standards. First, Factor loadings are more than 0.5 or higher (ideally 0.7 or higher) (see table 2), Second, Composite reliability CR (the overall reliability of the unobserved latent variable) is greater than 0.7 (ideally 0.8 or higher) (see table 2). Third, average variance extracted (AVE) (which shows the overall degree of variance in the observed variables accounted for by the unobserved latent construct) is above 0.5 which suggests adequate convergent validity as recommended by Hair et al., (2006). See table 2. 
Discriminant validity is also confirmed in the current study by comparing the AVE value for any two latent variables with the correlation estimates between the same two latent variables. The squared AVE estimates are greater than the correlation estimates, thus giving an evidence of discriminant validity. See table 2

\begin{tabular}{|c|c|c|c|c|c|c|c|c|c|c|}
\hline & CR & AVE & MSV & $\begin{array}{l}\text { Max } \\
\text { R0 }\end{array}$ & Integrity & Adaptability & Collaborative & $\begin{array}{l}\text { Results } \\
\text { Oriented }\end{array}$ & $\begin{array}{l}\text { Customer } \\
\text { Oriented }\end{array}$ & $\begin{array}{l}\text { Detail } \\
\text { Oriented }\end{array}$ \\
\hline Integrity & 0.95 & 0.81 & 0.47 & 0.95 & 0.90 & & & & & \\
\hline Adaptability & 0.93 & 0.66 & 0.45 & 0.97 & 0.61 & 0.81 & & & & \\
\hline Collaborative & 0.86 & 0.63 & 0.53 & 0.98 & 0.48 & 0.51 & 0.79 & & & \\
\hline $\begin{array}{l}\text { Results } \\
\text { Oriented }\end{array}$ & 0.95 & 0.86 & 0.46 & 0.98 & 0.61 & 0.61 & 0.65 & 0.93 & & \\
\hline $\begin{array}{l}\text { Customer } \\
\text { Oriented }\end{array}$ & 0.95 & 0.86 & 0.53 & 0.98 & 0.59 & 0.63 & 0.73 & 0.68 & 0.93 & \\
\hline $\begin{array}{l}\text { Detail } \\
\text { Oriented }\end{array}$ & 0.93 & 0.83 & 0.47 & 0.99 & 0.69 & 0.67 & 0.50 & 0.62 & 0.66 & 0.91 \\
\hline
\end{tabular}

\section{SEM Results and Interpretations}

Structural equation modeling was employed in the current study to serve two main purposes: first, to test the causal links between the study variables, second, to find out which organization culture practices can generate superior performance (CA) as compared to those organizations that have downmarket performance. AMOS v18 and the technique of ML estimation were employed.

Following Byrne (2016) procedures model 1 as drawn in Figure 3, which shows the relationships between OC and FP, is tested distinctly for two groups (superior FP (CA) and downmarket FP) to compute the GOF for each single model as shown in Figures 4 and 5. The GOF measure as drawn in figure 4 and 5, shows that both models ( 2 and 3 ) fit the data well, these results are consistent with previous studies that confirm the positive impact of OC as a multi-dimensional construct on the firm performance such as those by Kim et al., (2004); Oparanma (2010); Zheng et al., (2010); Duke II \& Edet, (2015) and at the same time these results contradict other results that show no positive impact of OC on FP (i.e. Kim et al., 2004; Yesil, and Kaya, 2013). This contradiction might be due to the different context or data analysis techniques employed.

Then model 1 as visualized in Figure 3 is analyzed in SEM by using the multi-group analysis technique to find out whether or not the structural model is equivalent or different across the previously mentioned two groups (superior FP and downmarket FP). 
Figure 3: model 1: Main model

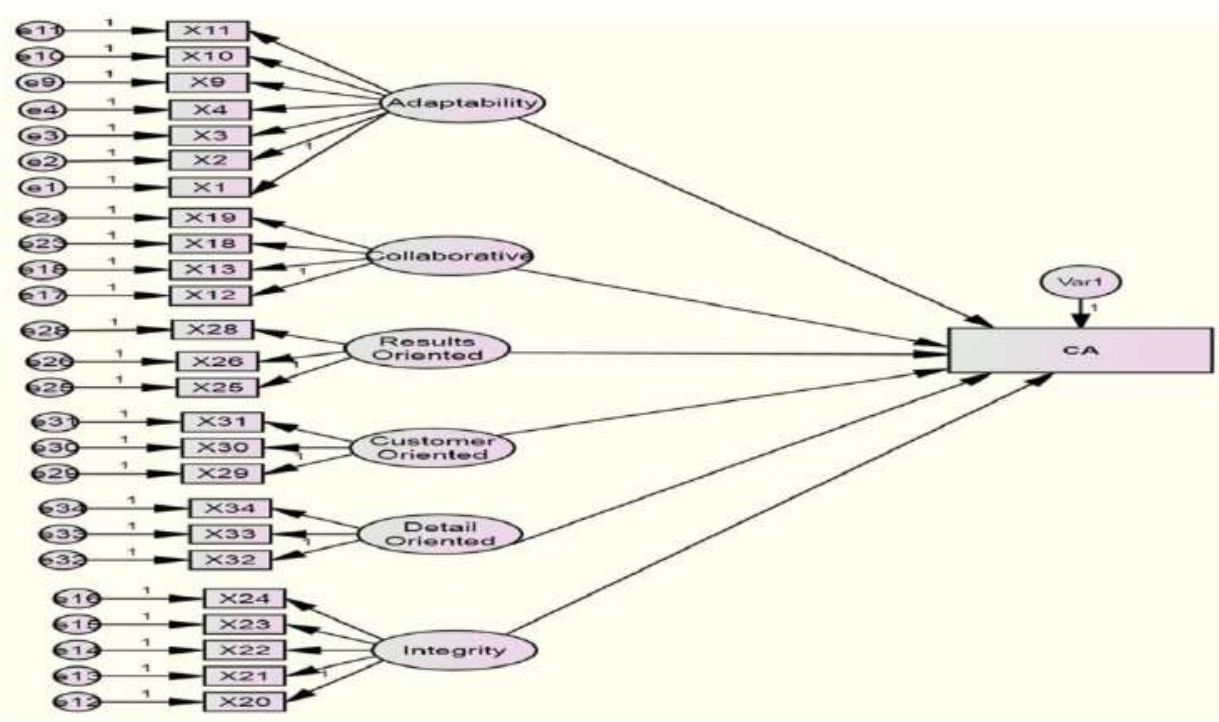

Figure 4: Model 2 OC and superior (above average) performance (CA) model

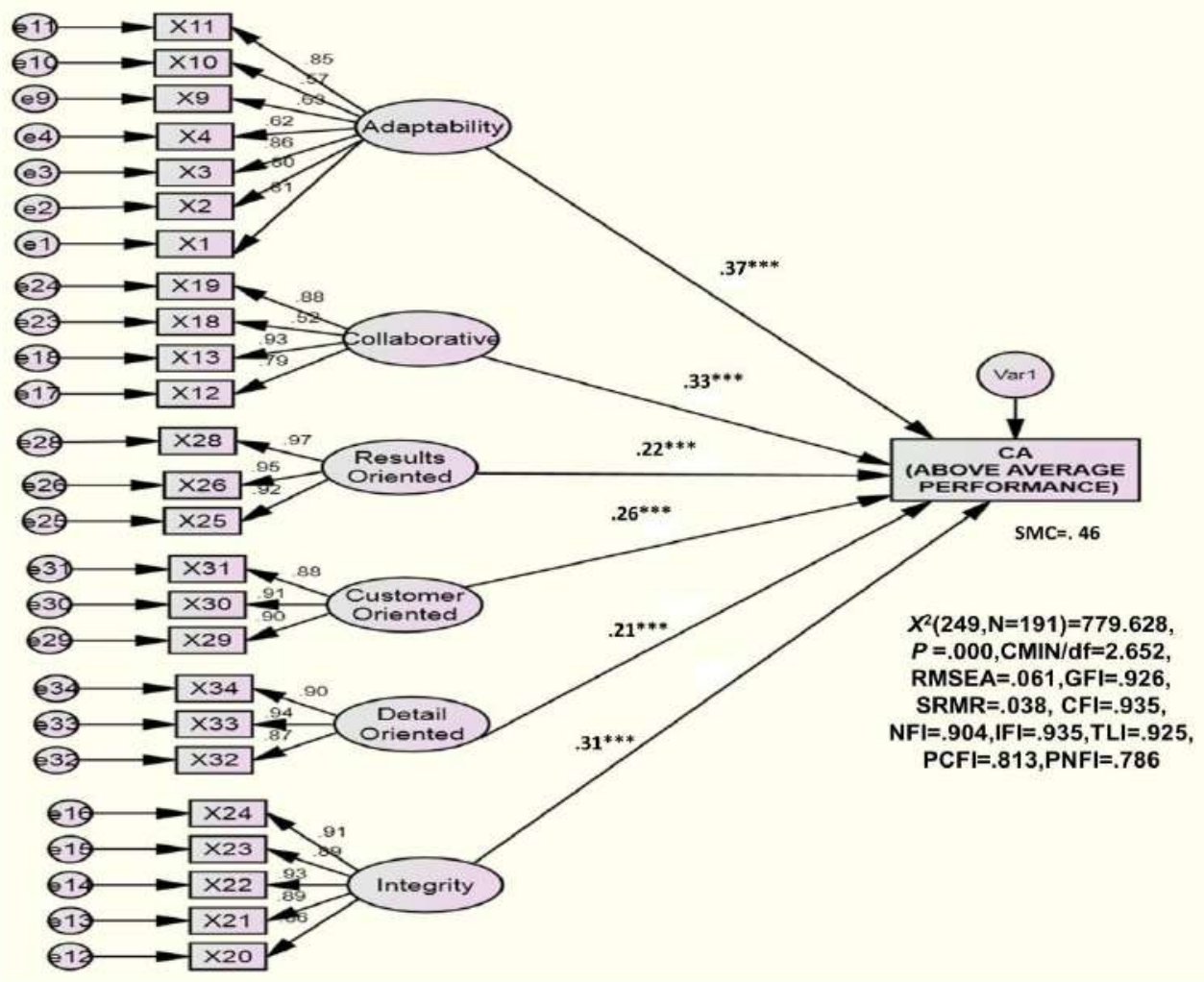


The impact of organization culture on competitive advantage" An empirical study of hotels and tour operators in Egypt."

Figure 5: Model 3, OC and downmarket (below average) performance model

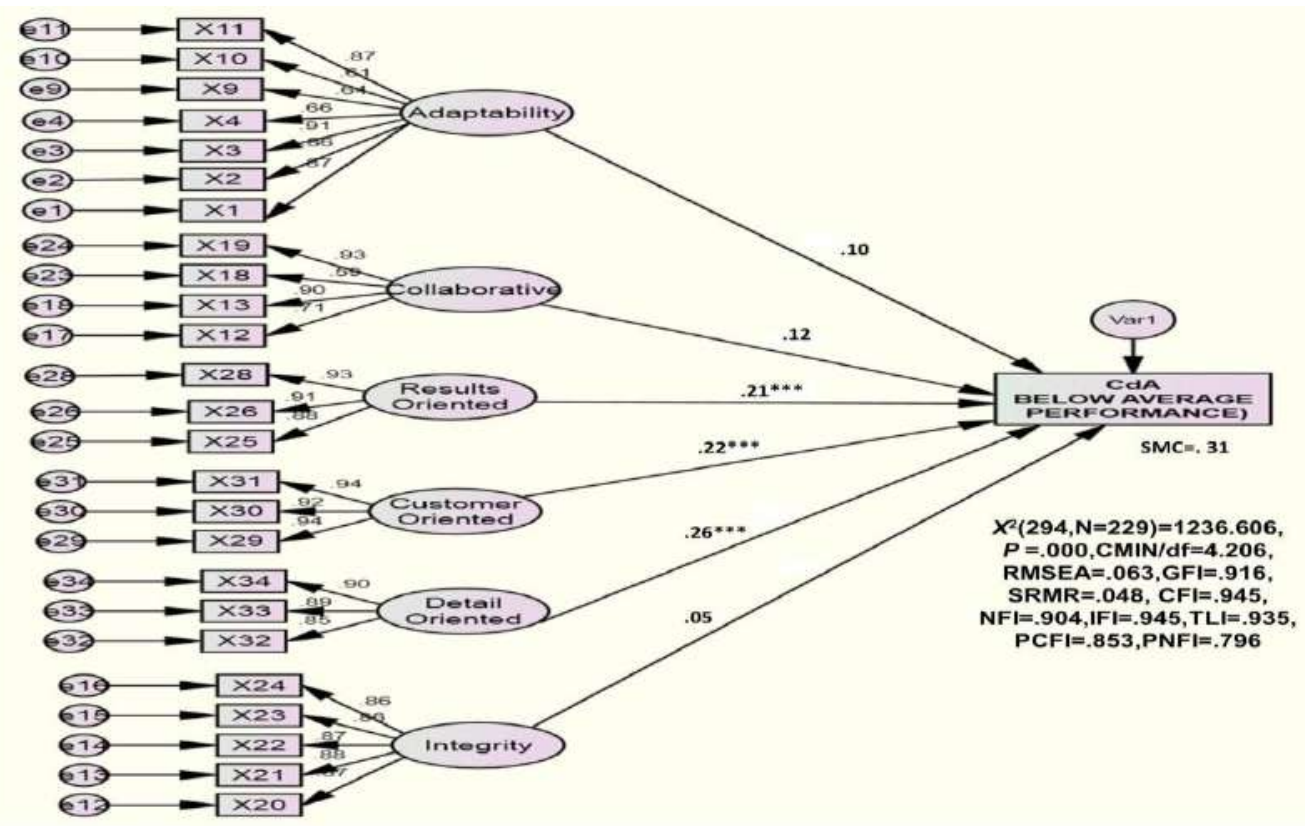

\section{Multi-group analysis}

This study might enhance our understanding of the nature of the relationship between OC and CA by identifying which OC practices give the firm (hotels and tour operators) a superior FP (as a measure of CA) over its rivals. Because financial performance as unobserved latent construct (measured by two items) cannot be divided to identify superior FP (competitive advantage) and downmarket FP, a composite one observed variable containing the average of revenue and employee productivity is employed in the model.

The two groups models (superior and downmarket FP) are compared to each other to find out the differences in paths from OC to FP, and thereby identify which OC give the hotel/tours operator a superior FP (competitive advantage) over its rivals.

An indication of invariance between the two groups can be constructed on $\chi^{2}$ values difference $\left(\Delta \chi^{2}\right)$ (Byrne, 2010). $\chi^{2}$ number of the configural /unconstrained model (2016.115) is equated with the similar values in the structural weights model (2168.389), If the value of the $\chi^{2}$ difference is significant at a probability $<0.001$, it can be suggested that one ( might be more than one) of the paths is not functioning equally across the groups (Byrne, 2010).

Table 3: $\chi 2$ difference between configural model and Structural weights models

\begin{tabular}{|l|l|l|l|}
\hline Model & CMIN & DF & P \\
\hline Unconstrained (configural model) & 2016.115 & 588 & .018 \\
\hline Structural weights & 2168.389 & 619 & .000 \\
\hline
\end{tabular}

As illustrated in table (3) the $\chi 2$ difference $(\Delta \chi 2)$ value is 152.274 with 31 degrees of freedom. This value is significant at a probability of $<0.001$. This evidence shows that firms that have superior performance $(\mathrm{CA})$ as shown in figure 4 implement different practices of $\mathrm{OC}$ from those firms that have downmarket performance as shown in model 5. 
As shown in model 4 and 5, three OC dimensions (result oriented, customer oriented and details oriented) have a positive significant impact on the performance (superior and downmarket performance), this result gives an evidence that these three practices of $\mathrm{OC}$ do not make any differences between the two groups of interest ( firms that have superior and downmarket performance). However, three other OC practices (adaptability, collaborative, and integrity) have a different impact on firms with downmarket and superior FP.

In other words, the empirical analysis gives evidence that hotels/tour operators who implement the adaptability practices of OC (i.e. employees are innovative, risk-taking, willing to experiment, fast-moving, quick to take the advantage of opportunities, not being constrained by many rules) outperform their rivals and can achieve a competitive advantage. In addition the collaboration practice of OC (i.e. employees are working in collaboration with others, team-oriented, cooperative, supportive, avoiding conflict, confronting conflict directly) and the integrity practice of OC (i.e. employees have integrity, high ethical standards, honesty, respect individuals, and fair) differentiate those firms that hasve superior FP from those firms that have downmarket FP (see figure 4 and 5). Conclusively, the empirical evidence shows that three practices of OC: (1) adaptability, (2) collaboration, and (3) integrity can establish a strong culture in the organization and therefore create a competitive advantage. Additionally, the predictive power (0.64) of model 2 (which tests the impact of OC on superior performance) is higher than the predictive power (0.31) of model 3 (which tests the impact of OC on downmarket performance). This result supports the assumption that the contribution of organization culture is significant to the success of firms that have superior performance over their rivals.

\section{Recommendation and Implication}

This study might contribute to the body of knowledge in different ways; first, the study gives empirical evidence that supports the positive impact of organization culture on the financial performance of hotel/tour operators in Egypt. Second, the current study might help in resolving the contradictory results of previous studies regarding the nature of the relationship between OC and FP. Third, this study might be (to the authors' knowledge) one of the first studies in the tourism industry that employed multi-group analysis in SEM to differentiate between two groups (superior and downmarket firms) regarding the implementation of the OC practices, to find out which OC practices generates CA. In other words, this study suggests that some OC practices (adaptability, collaboration, and integrity) can construct a strong culture in the organization and, in return, these organizations can easily outperform others with weak organization culture.

Again, this study gives recommendations to hotel and tour operator top management to focus on certain practices of organization culture to generate a competitive advantage. More specifically, organization culture is formed by the organizations' leaders (hotels and tour operators top manager), through years of influence and reinforcement and is therefore passed on to their subordinates in order to ensure their successful incorporation into the organization. So, leaders of organizations are responsible for the climate they create in their organization. For new employees, this would mean adaptive behavior (adaptability practice of OC) within the organization that leads to new belief systems. This new and adaptive behavior is instilled through organizational values to attain the organization goal (competitive advantage). Additionally, management should also believe that employees are more significant than rules in the organization. When a great number of the employees embraces the same kind of beliefs and values as concern to the organization, culture of association is (collaborative practice of OC) viewed as strong culture that can give the firm an opportunity to outperform its rivals, therefore hotel and tour operator top management should try to decrease the gap between employees to develop a strong relationship that can create a competitive advantage.

\section{Reference}

Abu-Jarad, I.Y.; Yusof, N.A. and Nikbin, D., (2010). A review paper on organizational culture and organizational performance. International Journal of Business and Social Science, 1(3).

Ahmed, P.K. (1998). Culture and Climate for Innovation. European Journal of Innovation Management, $1(1), 3043$.

Alvesson, M., and Sveningsson, S. (2015). Changing organizational culture: Cultural change work in progress. Routledge.book 
Barney, J., (1991). Firm resources and sustained competitive advantage. Journal of management, 17(1), pp.99-120.

Barney, J.B., (1986). Organizational culture: can it be a source of sustained competitive advantage?. Academy of management review, 11(3), pp.656-665.

Barney, J.B., (1996). The resource-based theory of the firm. Organization science, 7(5), pp.469-469.

Birnbaum, D. and Sommers, M. J. (1986). The influence of occupational image subcultures on job attitudes, job performance, and the job attitude-job performance relationship. Human Relations, 39, 661-672.

Bollen, K.A. and Paxton, P., (1998). Detection and determinants of bias in subjective measures. American Sociological Review, pp.465-478.

Brown, J. D. (1973). The Human Nature of Organizations. Nordic Journal of African Studies ,12(2): 164179 (2003). London: Pitman Publishing

Byrne, B.M., 2016. Structural equation modeling with AMOS: Basic concepts, applications, and programming. Routledge.

Cameron, K. S. and Quinn, R. E.(2006). Diagnosing and Changing Organizational Culture Based on the Competing Values Framework. JosseyBass, San Fransisco.

Cameron, K.S and Quinn, R.E. (1999), Diagnosing and Changing Organizational Culture. Based on the Competing Values Framework, Addison-Wesley, Reading, MA.

Davidson, G.M. (2003). The relationship between organisational culture and financial performance in a South African Investment Bank. Unpublished Masters Dissertation. University of South Africa. Pretoria.

Deal, T.E. and Kennedy, AA. (1982). Cultures: A new look through old lenses. Journal of Applied Behavioural Science, 19, 487-507.

Denison, D. (1990). Corporate culture and organization effectiveness. New York: Free Press

Denison, D. R. and Mishra, A. K. (1995). Toward a theory of organizational culture and effectiveness. Organizational Science, 6, 204-223.

Duke II, J. and Edet, G.H. (2012). Organizational Culture as a Determinant of Non-Governmental Organization Performance: Primer Evidence from Nigeria. International Business and Management, 4 (1), 66-75.

Earley, P.C. and Mosakowski, E.M. (2000). Creating hybrid team cultures: An empirical test of international team functioning. Academy of Management Journal. 43. 26-49.

Fekete H. and Böcskei E. (2011). Cultural Waves in Company Performance. Research Journal of Economics, Business And ICT, 3, 38-42. Field, A. (2005). Discovering statistics using SPSS (2nd ed.). London: Sage.

Glisson, C., (2007). Assessing and changing organizational culture and climate for effective services. Research on social work practice, 17(6), pp.736-747.

Gregory, B.T.; Harris, S.G., Armenakis, A.A. and Shook, C.L., (2009). Organizational culture and effectiveness: A study of values, attitudes, and organizational outcomes. Journal of Business Research, 62(7), pp.673-679.

Han, J.K.; Kim, N. and Srivasta, R.K. (1998). Market Orientation and Organizational Performance: Is Innovation a Missing Link?, Journal of Marketing, 62 (4), 30-45.

Hofstede, G. (1991). Cultures and organizations; Software of the mind, 6th edn, McGrawHill, New York.

Hofstede, G. (2011). Dimensionalizing cultures: The Hofstede model in context. Online readings in psychology and culture, 2(1), p.8.

Hogan, S.J. and Coote, L.V., (2014). Organizational culture, innovation, and performance: A test of Schein's model. Journal of Business Research, 67(8), pp.1609-1621. 
Ivancevich, J. M.; Konopaske, R. and Matterson, M. T. (2005). Organisational Behaviour and Management. (7th ed). Boston. McGraw-Hill. Irwin.

Kemp, S. and Dwyer, L. (2001). An examination of organizational culture- the Regent Hotel, Sydney. International Journal of Hospitality Management, 20, 77-93.

Kim Jean Lee, S. and $\mathrm{Yu}$, K. (2004). Corporate culture and organizational performance. Journal of managerial psychology, 19(4), pp.340-359.

Kotter, J. P. and Heskett, J. L. (1992). Corporate Culture and Performance, New York: Free Press

LeBlanc, C. L. and Mills, K. E. (1995). Competitive advantage begins with positive culture. Nation's Restaurant News, 29, 22-24.

Ledimo O. (2015). Diversity Management: An Organisational Culture Audit To Determine Individual Differences. Journal of Applied Business Research, 31(5), p.1733.

Lok, P and Crawford, J. (2003). The effect of organisational culture and leadership style on job satisfaction and organisational commitment: A cross-national comparison. Journal of Management Development, 23(4), 321-338.

Madu, B.C. (2012). Organization culture as driver of competitive advantage. Journal of Academic and Business Ethics, 5, p.1.

Maleka, N.K. and Kambuwa, M., (2015). Assessing organisational culture management and its impact on performance at sew eurodrive (sa).

Manetje, O. and Martins, N. (2009).The relationship between organisational culture and organisational commitment. Southern African Business Review, 13(1), 87-111.

Marchand, A.; Haines, V.Y. and Dextras-Gauthier, J., (2013). Quantitative analysis of organizational culture in occupational health research: a theory-based validation in 30 workplaces of the organizational culture profile instrument. BMC public health, 13(1), p.443.

Marcoulides, G.A. and Heck, R.H.. (1993). Organizational Culture and Performance: Proposing and Testing A Model. Organization Science, 4(2), 2009-225.

Martins, E.C. and Terblanche, F. (2003). Building organizational culture that stimulates creativity and innovation. European journal of innovation management, 6(1), pp.64-74.

Martins, N and Martins, E. (2003). Organisational culture. In Organisational behaviour: Global and South African perspectives edited by SP Robbins, A Odendaal and G Roodt (pp. 379- 400). Cape Town: Pearson Education South Africa.

Martins, N. and Von der Ohe, H. (2006). Detecting sub-cultures in an organisation. Southern African Business Review, 10 (2), 130 - 149.

Mazur, B. (2010). Cultural Diversity in Organisational Theory and Practice. Journal of Intercultural Management, 2 (2), 5-15.

Mooney, A.( 2007). Core competence, distinctive competence, and competitive advantage: What is the difference?. Journal of education for business, 83(2), pp.110-115.

Naik, N.A. (2011). Organisational culture and organisational commitment in a consulting firm (Doctoral dissertation).

O'Reilly, C.A.; Caldwell, D.F., Chatman, J.A. and Doerr, B., (2014). The Promise and Problems of Organizational Culture CEO Personality, Culture, and Firm Performance. Group \& Organization Management, 39(6), pp.595-625.

Oparanma, A.O. (2010). The organizational culture and corporate performance in Nigeria. International Journal of African Studies, 3, pp.34-40.

O'Reilly, C. (1989). Corporations, culture, and commitment: Motivation and social control in organizations. California management review, 31(4), pp.9-25. 
OReilly, C.A. and Chatman, J.A., (1996). Culture as social control: Corporations, cults, and commitment. Research in organizational behavior, vol 18, 1996, 18, pp.157-200.

O'Reilly, C.A.; Chatman, J. and Caldwell, D.F., (1991). People and organizational culture: A profile comparison approach to assessing person-organization fit. Academy of management journal, 34(3), pp.487516.

Porter, M.E. (1985). Competitive advantage: creating and sustaining superior performance. 1985. New York: FreePress.

Preissing, D. and Loennies, F. (2011). Organizational Culture and Integration of Older Employees: The German Experience. Journal of New Business Ideas \& Trends, 9 (1), 28-42.

Prem, S. (2011). The adaptation and evaluation of a measure of organizational culture in the mining industry in South Africa ,Doctoral dissertation, School of Business Leadership University of South Africa In partial fulfillment of the requirements for the masters

Robbins, S.P. (2005). Organisational behaviour. (11th ed). New Jersey, Prentice Hall.

Robbins, S.P.; Coulter, M., Sidani, Y. and Jamali, D., (2011). Management (Arab World Edition). England: Pearson.

Saffold, G.S. (1988). Culture traits, strength, and organizational performance: Moving beyond "strong" culture. Academy of management review, 13(4), pp.546-558.

Sánchez-Canizares, S.M.; Ángel Ayuso Muñoz, M. and López-Guzmán, T., (2007). Organizational culture and intellectual capital: a new model. Journal of intellectual capital, 8(3), pp.409-430.

Sarros, J.C.; Cooper, B.K. and Santora, J.C., (2008). Building a climate for innovation through transformational leadership and organizational culture. Journal of Leadership \& Organizational Studies, 15(2), pp.145-158.

Sarros, J.C.; Gray, J., Densten, I.L. and Cooper, B., (2005). The organizational culture profile revisited and revised: An Australian perspective. Australian Journal of Management, 30(1), pp.159-182.

Schein, E. H. (2004). Organizational culture and leadership. San Francisco: Jossey-Bass.

Schein, E.H. (1992). Organizational culture and leadership. San Francisco, CA: Jossey-Bass.

Schein, E.H. (1990). Organizational culture (Vol. 45, No. 2, p. 109). American Psychological Association.

Struwig, F. W. and Smith, E. E. (2002).The relationship between organisational culture and strategy formulation in South African firms. South African Journal of Business Management, 33 (1), 21-29.

Testa, M.R. and Sipe, L.J., (2011). The Organizational Culture Audit: A Model for Hospitality Executives.

Tidball, K. H. (1988). Creating a culture that builds your bottom line. Cornell Hotel and Restaurant Quarterly, 29, 63-69.

Trefry, M.G. (2006). A double-edged sword: organizational culture in multicultural organizations. International Journal of Management, 23(3), p.563.

Tseng, Shu-Mei. (2010).The correlation between organizational culture and knowledge conversion on corporate performance. Journal of Knowledge Management, 14 (2), 269-284.

Valmohammadi, C. and Roshanzamir, S.,( 2015). The guidelines of improvement: Relations among organizational culture, TQM and performance. International Journal of Production Economics, 164, pp.167-178.

Werner, A. (2007). Organisational behaviour: A contemporary South African perspective (2nd ed.). Pretoria. Van Schaik.

Xenikou, A. and Simosi, M. (2006). Organizational culture and transformational leadership as predictors of business unit performance. Journal of managerial psychology, 21(6), pp.566-579. 
Yesil, S. and Kaya, A. (2013). The effect of organizational culture on firm financial performance: Evidence from a developing country. Procedia-Social and Behavioral Sciences, 81, pp.428-437.

Zheng, W.; Yang, B.,. \& McLean, G. N. (2010). Linking Organizational Culture, Structure, Strategy and Organizational Effectiveness: Mediating Role Of Knowledge Management. Journal of Business Research, 63, 763771 .

Zu, X.; Fredendall, L.D. and Douglas, T.J., (2008). The evolving theory of quality management: the role of Six Sigma. Journal of operations Management, 26(5), pp.630-650.

العلاقة بين الثقافة التظيمية والميزة التنافسية: "دراسة تطبيقية علي الفنادق وشركات السياحة المصرية"

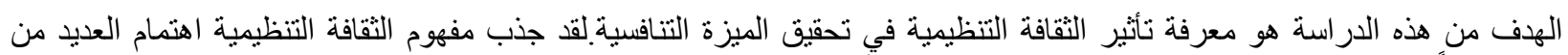

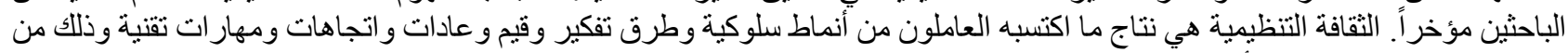

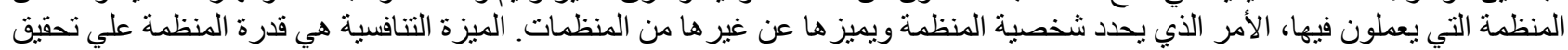

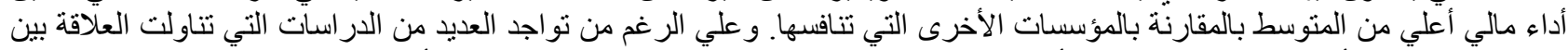

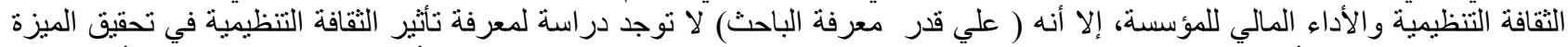

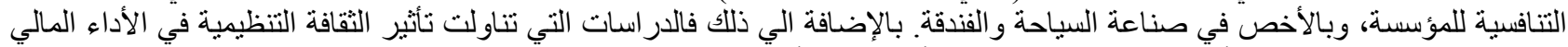
اختلفت في تحديد نوعية هذا التأثير هل هو إيجابي، سلبي، أو لا يوجد تألثئير.

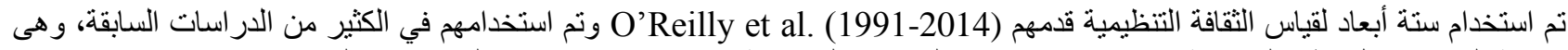

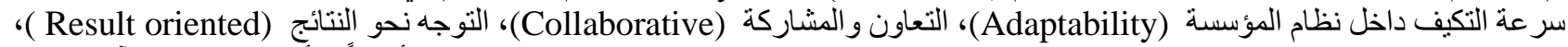
(Customer oriented ( التوجه نحو العميل ) التوجه نحو التفاصيل (Detail oriented ) ، وأخيراً الأمانة واحترام الآخرين ) ) . Integrity)

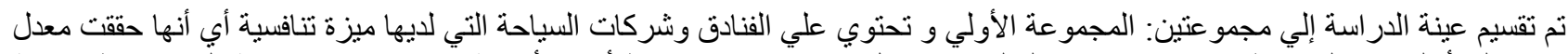

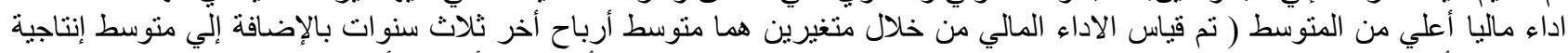

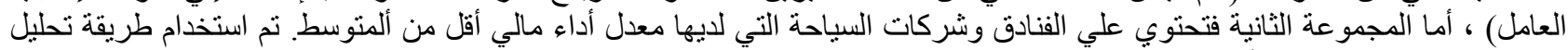

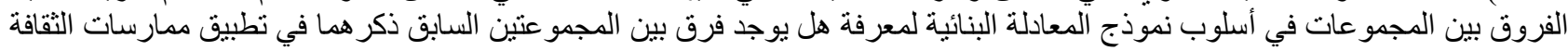
التنظيمية.

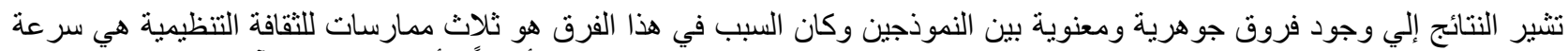

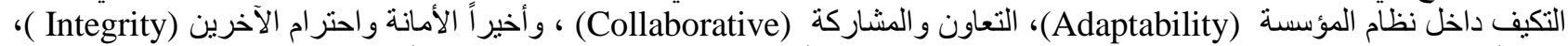

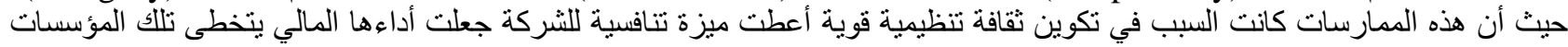
ذات الثقافة التنظيمية الضعيفة والتي ركزت فقط علي بعض ممارسات الثقافة التنظيمية وهي ، التوجه نحو النتائج (Result oriented ) ، التوجه نحو العميل (Customer oriented ) ، التوجه نحو التفاصيل (Detail oriented) . 